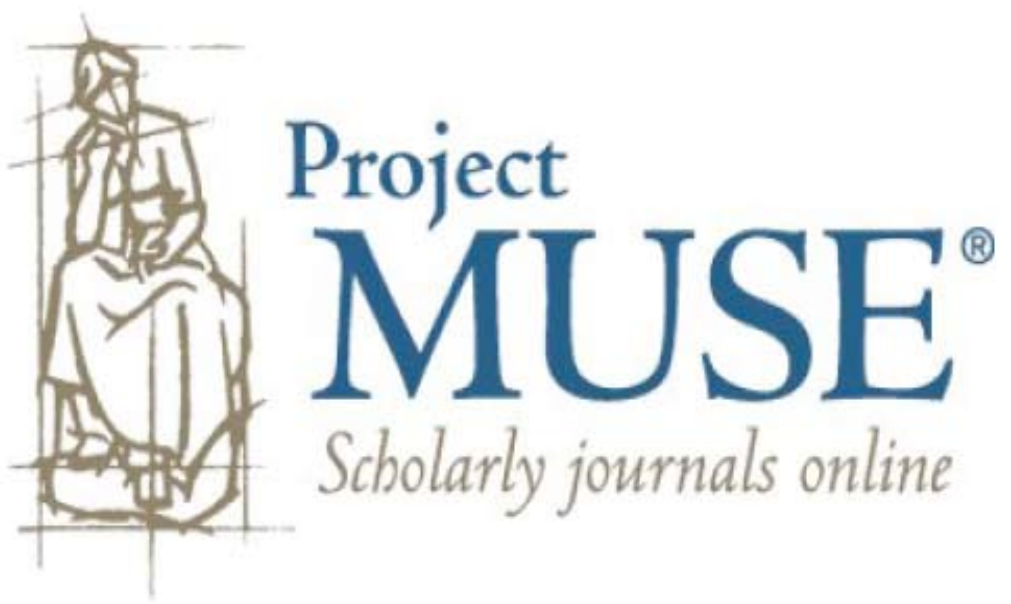




\title{
Encrypted Sympathy: Wordsworth's Infant Ideology
}

\author{
Ortwin de Graef \\ Katholieke Universiteit Leuven
}

The province of ethics and literature is arguably one of the more prominent places where the study of literature has been acting out its constitutive legitimization crisis over the past decade or so. As Steven Connors remarked in a 1996 review of, among others, David Parker's Ethics, Theory and the Novel, "the word 'ethics' seems to have replaced 'textuality' as the most charged term in the vocabulary of contemporary cultural and literary theory" (Connors 1996: 24; see also Hadfield, Rainsford, and Woods 1999: 1); and in his introduction to the 1999 $P M L A$ issue on "Ethics and Literary Study," Lawrence Buell makes much the same point, although slightly less confidently, when he states that "[e]thics has gained new resonance in literary studies during the past dozen years, even if it has not - at least yet - become the paradigm-defining concept that textuality was for the 1970s and historicism for the 1980s" (1999: 7). As Buell's reservation suggests, it is still doubtful whether the ethical tremble running through literary scholarship is likely to gather to a thunder. In fact, there are indications that it is already dying down, or was indeed always already drowned out by alternative thrills such as globalization, which, we are told by the organisers of an international summer seminar in literary studies that took place in 2000 , is the real "literary-critical catch-all" for the 1990s. ${ }^{1}$ The fact that the previous edition of this seminar was called Reading Text, Constructing Theory, Thinking Ethics (London 13-20 June 1999) quietly confirms that ethics was on the agenda in the 1990s, though not, it would now appear, as a genuinely core-building concept.

At any rate, it is clear that contemporary literary scholarship has witnessed a marked increase in the deployment of ethical rhetoric and

1 Flyer for the International Seminar on 'European Literature(s), ' World Literature(s),' and 'Globalization,' Monday 19-Friday 23 June, 2000, Leiden, organised by the Netherlands Graduate School for Literary Studies in cooperation with University College London and Aarhus University. 
that this turn to ethics is received as a turn away from, typically, text and history. A plausible, if roughly-drawn, account of the paradigm parade of literary studies over the past few decades could run more or less as follows: in the 1970s and early 1980s, deconstruction, with its textual fixations, figures as a dominant point of reference in the then current critical discourse; in the course of the 1980s, the alleged textualist idealism of deconstruction increasingly comes under attack and is gradually ousted by approaches such as New Historicism and PostColonial Studies, which profile themselves as more properly responsive to "real" issues of history and politics and as less starry-eyed about the supposed privilege of (Canonical) upper-case Literature, thereby relocating the study of literature within the larger project of Cultural Studies; the ethical turn of the 1990s, then, appears to herald - at least on the face of it - a dismissal not only of the sterile impersonality of textualist idealism but also of the ideology-critical overkill of resolutely politicised reading and of the paradoxical levelling abstractions of historical particularism. Reading literature under the aegis of ethics promises a recovery of a more human and humane appreciation of literature as humanism in personal practice, an intimate exercise in increasing awareness, and fostering understanding.

In the words of Martha Nussbaum, who has established herself as a prime representative of the principle, if not therefore the practice, of ethical criticism, the "literary imagination" released in this reading is "an essential ingredient of an ethical stance that asks us to concern ourselves with the good of other people whose lives are distant from our own" (1995: xvi) and thereby in turn releases us "from a stifling confinement into a space of human possibility" (1998: 362). The literary imagination so conceived, Nussbaum contends, "is an essential part of both the theory and the practice of citizenship" (1995: 52). As this last claim indicates, the ethical turn that is at stake here is emphatically not a matter of private imaginings alone; on the contrary, the release of sympathy effected by the literary imagination is seen as a powerful catalyst in the formation of a political community. The question this raises, though, is how the literary text actually performs such a saving release; or perhaps more accurately: how it saves records, stores, preserves, encrypts - the civic virtue of sympathy itself. $^{2}$

2 The present essay is part of a more extended study of the ideology of sympathy 


\section{Europe's Latter Hour}

In The Fateful Question of Culture, a series of lectures delivered in 1992 and reworked for publication in 1997, Geoffrey Hartman offers an extreme example of this putative participation of the literary imagination in the formation of good citizenship. Hartman's track record as a scrupulous reader of literature is such that placing him in the company of Nussbaum comes close to committing a categorymistake - but this may not be inappropriate in the context of ethics, characterised by Geoffrey Galt Harpham as "the locus of otherness [which] perhaps ought to be considered a matrix, a hub from which various discourses, concepts, terms, energies, fan out and at which they meet, crossing out of themselves to encounter the other, all the others" (1999: 37; see also 1992: 17). More substantially, though, what unites both scholars is their emphatically stated belief in the civilising power of the literary imagination.

In Hartman, the twin convictions that "the work of a great artist can have a strong and long-range impact on the way we look at ourselves as a culture" (1997: 7) and that the "beneficial" nature of this impact (1997: 16n. 13), as he discovers it in his test-case Wordsworth, in principle characterises all Great Literature as such, amount to a veritable profession of faith. Appealing to our critical charity in his opening movements, he first concedes: "Since Wordsworth's poetry is only one example, and I do not test other explanations for the specific influence it exerted in England, I claim for my thesis no more than heuristic value" (7). But no sooner has he made this concession than he reclaims an unassailable authority of feeling for his faith in literature as a salvational force: "But were my conjectures to be disproved or shown incapable of being proved, I would continue to feel as Mr. Henshaw does, in Willa Cather's My Mortal Enemy: 'How the great poets do

which proposes to trace this faculty from its influential codification in Adam Smith's Theory of Moral Sentiments to contemporary revisions in largely liberal or liberal-humanist public discourse and practice, with specific emphasis on the deployment of literature as an ideological apparatus (though not, typically, a state apparatus). The centrality of the notion of sympathy to Wordsworth's thought, my principal concern in what follows, is well-established, though I hope to further demonstrate the precarious nature of Wordsworth's "politics of sympathy" (Simpson 1987: 160) in specific textual detail in order to contribute to a reconsideration of its recovery today. 
shine on...! Into all the dark corners of the world. They have no night'" (7).

The level of defiance and the manner in which it is voiced here are non-trivially reminiscent of Tennyson's outcry in the face of the corrosive impact of science on faith in In Memoriam:

If e'er when faith had fallen asleep,

I heard a voice "believe no more"

And heard an ever-breaking shore

That tumbled in the Godless deep;

A warmth within the breast would melt

The freezing reason's colder part,

And like a man in wrath the heart

Stood up and answered "I have felt." (CXXIV, 11. 9-16)

The resonance of this unsolicited Tennysonian echo in Hartman's profession of faith is richer than may appear at first sight. For Tennyson's uneasy appreciation of the advances of evolutionary theory and geology finds its fainter latter-day translation in Hartman's uncomfortable recognition of the claims of deconstruction and New Historicism. To the former, to whose formation in literary scholarship he was a privileged participant witness, Hartman now addresses a question to end all questioning:

The question of our speech, the contemporary question, asks how long critical discourse must remain critical: that is, questioning; that is, in a negative mode. Can an affirmation emerge from all this splendid - cerebral, demystifying, deconstructive - "labor of the negative"'? (1997: 43)

Yet the affirmations emerging from New Historicism also fail to satisfy him. In a footnote added to the lectures prior to their publication in 1997, Hartman takes some pains to distinguish his own concept of "cultural causation" (1997: 16n.13) - the aforementioned "strong and long-range impact on the way we look at ourselves as a culture" issuing from "great artists" (7) - from that of New Historicism. More specifically, he approvingly registers Louis Montrose's attempt to chart the dialectic of "social text" and "shaping fantasies" in Shakespeare's plays but ultimately finds Montrose's argument wanting in precision: 
what is hard to distinguish here is the precise influence of the artist's work: there is often a dialectical blur as Shakespeare becomes a sort of primal historical scene, the paradigm case of a rich interplay that could go on and on, without a clear result except the work of art itself. The so-called dialectic, then, ends in a swollen moment of stasis. (1997: 16n.13)

If deconstruction, then, fails to come up with an enabling affirmation, and New Historicist interpretation does not succeed in establishing its affirmations by dint of its failure to convincingly demonstrate "the actual sociopolitical impact" of the literary work (1997: 16n. 13), the question is what, precisely, Wordsworth allows Hartman to affirm as an alternative. Given the substance of his self-confessedly immodest claim about Wordsworth's "precise influence," Hartman's defiance in the face of potential disproof or reservation is not entirely surprising - for the stakes involved are quite as decisive as the existence of God was to Tennyson: it is thanks to Wordsworth that England has been spared the disastrous deployment of "a cultural and political antimodernism vulnerable to vicious dichotomies" (79) witnessed on the European continent; it is Wordsworth's poetry which "helped to create the sense of a particularly English culture," and "this saved English politics from the virulence of a nostalgic political ideal centering on rural virtue, which led to serious ravages on the continent" (7). Hartman's carefully imprecise phrases - "vicious dichotomies," "serious ravages" - barely conceal the breathtaking thrust of the thesis advanced: it is Wordsworth's poetry which prevented the Holocaust from crossing the Channel; it is thanks to Wordsworth that England witnessed the emergence not of National Socialism but of the National Trust. ${ }^{3}$

It would be all too easy to simply dismiss this thesis as the idiosyncratic expression of gratitude of a German Jew who was forced to leave his home country at the age of nine and found refuge in England for the duration of World War II - though there is no doubt that this experience powerfully marks Hartman's thought (see Hartman 1999: xii and Caruth 1996: 650-52; see also Harpham 1999: 215-16). Neither would it be adequate to debunk Hartman's argument by merely marshalling as counterevidence the very existence of the British Union

3 On Wordsworth's posthumous role in the founding of The National Trust for Places of Historic Interest or Natural Beauty in England, Wales, and Northern Ireland, see Gill 1998: 235-60. 
of Fascists, or by complicating and compounding the brutal pun on the National Trust by confronting it with the National Front. Hartman does, after all, carefully weigh his words, and his reluctance to drive home the thesis he intimates deserves to be respected, precisely because it involves a crucial component of the special power of cultural causation with which he credits Wordsworth's literary imagination.

The Fateful Question of Culture opens by invoking an all too familiar challenge to literature and the study of literature: "everyone, it seems, wants to make art more accountable, to prove its social or material effectiveness" (1). The interest of Hartman's response to this challenge is what he calls his "main purpose": "to restore literature's specificity as a focus for thinking about culture" (2). This specificity involves literature's peculiar power of representation, a power which, in Wordsworth at least, "does not reflect in any simple way an existing situation [but] surrounds it, rather, with an imaginative aura" (7): literature "does not represent what is the case but brings something virtual into existence, which then has the force of imaginative fact" (13). Wordsworth's particular achievement in using this power is that he has succeeded in mediating modernization, the "catastrophic transition" (147) from an agrarian-rural to an industrial-urban society, and that, in doing so, he has provided England with a non-aggressive alternative to the sinister "unprogressive, overidealized, image of what is lost" (73) which, on the continent, led to "serious political consequences" (73). If culture can, among other things, be seen to have a "harmony-restoring function" which "cures the alienation and loss of community inflicted by society's emergence from a more primal and unreflected unity" (8), its intentness on "unity of purpose and unwoundedness of soul and body" (123) is also always in danger of fulfilling itself in the "perverse Nazi concept of Kultur" (127), in the "sinister unification" of Mein Kampf, and in the "absolute integration" of genocide (123). The "specificity" of Wordsworth's poetry is, therefore, that its "rhetoric of community" (66) envelops the trauma of transition with an imaginative aura that heals and thus preserves the wound instead of disastrously denying it in an absolute and phantasmal reintegration.

But what, precisely, is this "imaginative aura"? What are Wordsworth's "imaginative facts" which have ushered England into modernity whilst preserving it from the serious consequences ravaging the continent? What is the nature of Wordsworth's healing power, 
disastrously denied to continental Europe in its latter hour? Towards the end of his high argument, Hartman identifies this power with reference to the Blessed Babe passage of The Prelude:

The slogan of the Enlightenment, which Kant affirmed in his pamphlet on the subject, was "dare to know." The romantic poets added "afford sympathy": dare to feel. Wordsworth stated his hope that mature knowledge would not have to be "purchased" by the loss of power, where by "power" he meant the "Infant sensibility / Great birthright of our being" and its evolution into "A virtue which irradiates and exalts / Objects through widest intercourse of sense." (159)

In Wordsworth's text, however, the relation between "infant sensibility" and "virtue" - phrases separated by some 25 lines, with the latter, moreover, preceding the former - is not quite one of straightforward "evolution." But rather than to worry away at this well-worn early passage of The Prelude, I propose to turn to another infant, one which occupied Wordsworth a few years earlier and which may cast an alternative light on the purchase of his virtuous sympathy.

\section{Plain Speech}

Ever since their publication in 1975 as the inaugural volume of The Cornell Wordsworth, the Salisbury Plain poems have been a favorite site for critical Wordsworth scholarship. In particular, the substantial rewriting of the first text, Salisbury Plain - composed and abandoned in 1793-1794 - into Adventures on Salisbury Plain, which took place between 1795 and 1799, has proven to be an inevitable obstacle to be overcome in any conspectus of Wordsworth's literary history. Stephen Gill's editorial preface to the 1975 volume characterises these two texts, neither of which Wordsworth published, as "poems that troubled Wordsworth in his youth" but "recaptured his imagination in old age," when he returned to this "intractable material" and finally published what he then made of it as the 1842 poem Guilt and Sorrow $(S P P \times v) .{ }^{4}$

4 All quotations are taken from the Cornell Wordsworth edition (Wordsworth 1975). For convenience, references will be given as follows: SP for Salisbury Plain, ASP for Adventures on Salisbury Plain, GS for Guilt and Sorrow, each time followed by the line 
Gill gingerly steps around the question why Wordsworth failed to develop the Salisbury Plain matter for publication in the 1790s: the "poet's struggle," he notes, "was left unresolved as Wordsworth entered the period of his greatest achievement," and since the aim of the Cornell edition is "to give the factual evidence of Wordsworth's efforts to be true to his developing vision," the editor has decided to "avoid critical pronouncements" in his introduction and notes, "confident that the evidence presented here will speak plainly enough to the reader of Wordsworth's artistic integrity, energy, and power" (SPP xv).

Gill's confidence in the plain speech of Salisbury Plain has not, however, been rewarded in any straightforward fashion: to be sure, there is a vague consensus about the way in which the revisions sustain Wordsworth's "developing vision," but it is by no means clear what that vision actually reveals. In order to appreciate this confusion, a brief survey of the fields is required.

Salisbury Plain is a poem emphatically framed by an explicit narrative voice. The opening stanzas deliver a critical historical exercise in comparative suffering, where the present is diagnosed as a period in which the poor are far more radically depressed by pain and "Penury" (SP 1. 27) than the "hungry savage" (1. 3) of prehistoric times. The latter never knew any better, while the present-day deprived are tormented by "memory of pleasures flown" (1.21) and by "reflection on the state / Of those who on the couch of Affluence rest" (1l. 24-25). The poem then focuses on one representative of the "many thousands" (1. 34) suffering from deprivation today - a solitary traveller looking for shelter on Salisbury Plain. He comes upon the ruin of a "lonely Spital" (1.123), which he finds already occupied by "a female wanderer" (l. 138) who eventually begins to relate her life-story.

The female wanderer recollects her happy childhood "[b]y Derwent's side" (1.226), rudely interrupted when "cruel chance and wilful wrong" (1. 255) ruined her father. Fortunately, "[t]here was a youth" (1. 271) who saved them: the woman's young lover, who had been ordered by his father to a distant town "to ply remote from groves the artist's trade" (1.28l), takes them in. They marry and have children, the father eventually dies, just as the British - American War breaks out, and the family once again descends into poverty. Too proud to beg, the husband

number(s). References to the editorial matter and to manuscript transcriptions will be given as $S P P$ followed by the page number. 
joins the army, and the family follows in his train to America, where all but the woman perish. At this point, the tale is briefly interrupted by a scene suggesting some therapeutic effect in confiding in a friendly ear, after which the woman resumes her story up to the present: she was taken on board a British ship, lost her mind for a while, and was finally dropped off in England again, where she has been wandering for the past three years. The closing stanzas return us to the oratory of the narrator, who bursts into a full-blown performance of Enlightened revolutionary rhetoric, calling on the "Heroes of Truth" to "uptear / Th'Opressor's dungeon from its deepest base" (11. 541-52) and to wield "the herculean mace / Of Reason" (11. 544-45).

The most immediately striking change in the revision of the poem, most of which was completed already in the following year, is the neartotal erasure of the outer frame - as Gill puts it, "the poet as homilist," addressing "the statesmen of England on the corruption and oppression that are ravaging the nation... has almost disappeared" (SPP 3). The oratorical opening of the first poem is cut, and in its stead the reader is immediately confronted with the lonely traveller, who meets an old Soldier on his way to help his destitute daughter. The traveller offers the Soldier friendly support, secures a place for him on a passing post carriage, and resumes his journey alone. If in the first poem the character of the lonely traveller was not given much by way of personal history, in the revision he is turned into a Sailor with a full-fledged and pathos-laden past. Returning from a long sea journey, he was seized by a press gang and spent years in battle. Back in England, he was denied wages and found himself forced to return home " $[\mathrm{b}]$ earing to those he loved nor warmth nor food" ( $A S P$ 1.94), but just before he reaches his house, his desperate mood drove him to rob and murder a traveller, "[a]nd when the miserable work was done, / He fled, a vagrant since, the murderer's fate to shun" (11. 98-99). Having imparted this background knowledge, the poem returns to the present. Travelling along, the Sailor passes a gibbet with a human body hanging from it; the spectacle shocks him into an anguished "trance" (1. 126), which, having passed, leaves him with a soul sunk "into deepest calm" (1. 129).

The text then picks up the narrative of the earlier version: the Sailor meets the female wanderer in the Spital, and she relates her life-story. ${ }^{5}$

5 Such, at least, was Wordsworth's evident intention ("The woman thus began her 
The principal difference between this story and that which appears in the first Salisbury Plain poem concerns the period between the woman's return to England from America and her encounter with the Sailor. In the first poem, this period was covered by the mere elliptical indication "[t]hree years a wanderer round my native coast" (SP 1. 388); in Adventures on Salisbury Plain, however, it is packed with further detail. The woman loses her mind, falls unconscious, and is borne away to a hospital; upon recovery, she is dismissed and finds her "first relief" among a "wild brood" (1.503) of "[t]he rude earth's tenants" (1. 506) who make a living from "midnight theft" (1.524). Unable to accept this way of life for long - she feels she has "abused" her "inner self" and "[f]oregone the home delight of constant truth" (11. 547-48) - the woman resumes her solitary wandering and eventually encounters the Sailor.

Eschewing the inflammatory flourishes of the conclusion of the earlier poem, the second poem pulls itself together in an extended melodramatic resolution. The Sailor and the Female Vagrant travel on together, the former plagued by renewed anguish, the latter blessed with a sense of "new delight and solace new" (11. 574). They arrive at a cottage where they are welcomed and fed, after which the Female Vagrant sets out again on her own. She encounters a horse cart with a dying woman on it and escorts it back to the cottage, where it transpires that the dying woman is the Sailor's wife, who was turned out of her house when suspicion arose that her husband had murdered the traveller. The Sailor cries for forgiveness, on hearing his voice the woman dies, the Sailor confesses and is duly hanged.

This, then, is the backbone of the case for what Gill calls Wordsworth's "developing vision" ( $S P P \mathrm{xv})$. Despite his professed intention to avoid "critical pronouncements," Gill does sum up his understanding of this developing vision in terms that are commonplace in Wordsworth criticism:

Adventures on Salisbury Plain is both a continuation and a consummation of Salisbury Plain. It continues the social and political interests of the poem, and even extends them, but this

story to relate" $[A S P 1.261])$, though the manuscript does not contain the story itself. The Cornell Wordsworth edition convincingly inserts the text which later appeared in Lyrical Ballads as "The Female Vagrant." 
continuing attack on the government of the country does not draw on any really new response to contemporary conditions. There were many good reasons why the attack should continue, and it is successful because the rhetoric of Salisbury Plain has been replaced by a fully dramatized presentation of the human calamities consequent upon war, but Wordsworth's interest was rapidly shifting from social and political phenomena to the more complex phenomena of human motives and behavior. (SPP 12)

From "rhetoric" to the "presentation of human feelings through fully realized dramatic situations" (SPP 13), from social and political phenomena to the more complex phenomena of the human: these are not only commonplaces in critical accounts of Wordsworth's growth to maturity - they are what many take to be the organizing terms of the ethical turn in literary studies today. ${ }^{6}$ The standard chart of "Wordsworth's progress towards a more mature art" (Rieder 1997: 97) prefigures the shift from "the paradigms of 1970 s textuality and $1980 \mathrm{~s}$ historicism" to "the scene of interpersonality, or interhumanity" (Buell 1999: 16) occupying, and occupied by, a considerable section of contemporary literary scholarship. The move from Salisbury Plain to Adventures on Salisbury Plain offers an intimation of the imitation of Wordsworth that appears to be upon us. A more detailed examination of one particular passage in this move, however, will allow us to complicate this pattern and to reconnect it to Hartman's concept of healing power.

\section{The Invention of the Infant}

On their way to the cottage at the close of the poem, the Sailor and the Female Vagrant are disturbed by a shrill scream, followed by a blaspheming "hoarser voice" and "female cries" (ASP 11. 609-11).

Their course they thither bent

And met a man who foamed with anger vehement,

${ }^{6}$ For a richly detailed account of the shift from "the radical idiom of The Rights of Man" to "the insight of the imaginative poet" in the universe of discourse in which Wordsworth's Salisbury Plain poems were produced, see Roe 1988: 124-35. Alan Liu's advanced mapping of this process as a "domesticat[ion of] political agon" (Liu 1989: 222) remains exemplary. 
A woman stood with quivering lips and wan, Near an old mat with broken bread bestrown; And pointing to a child her tale began.

Trembling the infant hid his face (11. 613-16)

The woman relates how the child had taken the place of the father, who had got up to fetch a pitcher, and had failed to obey when asked to move, upon which the father began to beat the child "as if each blow had been his last" (1. 627). The Sailor orders the father to stop, and is answered with "bitter insult and revilings sad" (1.634), including the unwittingly appropriate prediction that he will meet his end hanging from the gallows. The Sailor does not reply but strokes the child still lying on the ground; when the boy turns his head, the Sailor notices he is bleeding from the very spot where he had "fix" $d$ " the "deadly wound" on the man he had murdered (1l. 644-45), and the sight reduces him to tears and to interior monologue:

Within himself he said, "What hearts have we!

The blessing this the father gives his child!

Yet happy thou, poor boy! compared with me,

Suffering not doing ill, fate far more mild." (11. 649-52)

The father, in turn, comes to his senses, kisses the boy, and "all [is] reconcil'd" (1.655).

Then with a voice which inward trouble broke In the full swelling throat, the Sailor them bespoke.

"Tis a bad world, and hard is the world's law; Each prowls to strip his brother of his fleece; Much need have ye that time more closely draw The bond of nature, all unkindness cease, And that among so few there still be peace:

Else can ye hope but with such num'rous foes

Your pains shall ever with your years increase."

While his pale lips these homely truths disclose,

A correspondent calm stole gently on his woes. (11. 656-66)

Several critics have singled out this beaten-child episode as a privileged moment in the progress of the poem. John Rieder, in Wordsworth's Counterrevolutionary Turn, sees this "crucial turn towards the poem's 
resolution" as "a scene of lower-class corruption being conquered by sympathy and domestic virtue" (1997: 105). As such, the scene fits in with what Rieder diagnoses as "a partial displacement of the paradigm of political virtue operating in Salisbury Plain by that different set of virtues associated with the sympathetic passions rather than rational judgment" (93): it betrays Wordsworth's recognition that his characters are not in a position to appreciate political virtue since they are "excluded from political participation" (105). Rieder argues that the principal effect of the Sailor's "homely truths" consists in the disclosure of "a drastic gap between the limited sphere in which the 'bond of nature' can assert itself and the 'bad world' of legal oppression and commercial rapacity" (106):

In Adventures on Salisbury Plain public problems find only private solutions, as the entire poem moves progressively from the disclosure of the miseries inflicted upon its main characters in the bad world to a more intimate setting where the characters' virtue is competent. In the sailor's speech, as in the poem, this region of self-determination, so to speak, is first that of the family and finally, in the stanza's final line, contained within the conscientious individual. (106)

Rieder recognizes that this entails a disturbing plea for a "resignation to the unbridgeable gap between public vice and private virtues" (106), which, moreover, sits uncomfortably with the characters' continuing and active commitment to the organizing discourse of the public world, as witness their emphatic assent to the Sailor's public execution. Yet such an inconsistency, it would appear, is the price to be paid for a proper representation of the politically unrepresented. If in the first poem Wordsworth comes close to "exhibiting [his characters] as evidence in a brief against the state" (93), his attempts to rewrite this evidence in terms of what Rieder recognizes as an "ethical problematic" (50) appear to be in danger of abandoning them in the last-ditch retreat of a dumb domesticity so enclosed upon itself that it cannot see citizenship as anything other than an incomprehensible curse. Practitioners of ethical criticism following Nussbaum's call for a release "from a stifling confinement into a space of human possibility" (1998: 362) are not likely to find such release in this passage on Salisbury Plain.

Rieder concludes his reading of the Salisbury Plain poems with his own version of Wordsworth's developing vision: 
The development of Wordsworth's thematics moves from public discords toward their private, individual roots. But this kind of radicalization passes from explicitly addressing itself to political actors to the contemplation of those who suffer politics from afar. In the process, Wordsworth's poetry becomes more reflective precisely because the poor lack the competence to understand their problems from the broader perspective available to the poet, and thus the polemical force of representing them derives from their mute objectivity, in which the poet of humanitarian protest finds his own sympathies reflected back to him in a socially pertinent way. (Rieder 1997: 107)

The question remains, though, what precisely is left of "the broader perspective available to the poet" in this process. Put bluntly: how does the poet understand the relation between the bad world of the state, which "the poor lack the competence to understand" (107), and the limited sphere of the family, where their "virtue is competent" (106)? Competent for what? Does the poet understand this relation at all? And if so, how exactly do the "sympathies" informing his developing vision contribute to the practice and theory of citizenship? What is the "polemical force" and the social pertinence of Wordsworth's imagination?

In his recent study Romanticism on the Road: The Marginal Gains of Wordsworth's Homeless, Toby Benis, also focussing on the childbeating episode, goes some way in addressing the contradictions that Rieder leaves suspended by turning Wordsworth's vision in an entirely different direction. Benis's perspective is partly governed by his productive misreading of the four opening stanzas of the original poem, which set up the contrast between the suffering savage and the present-day poor. In the first stanza, Wordsworth evokes the plight of the savage:

Hard is the life when naked and unhouzed

And wasted by the long day's fruitless pains,

The hungry savage, 'mid deep forests, rouzed

By storms, lies down at night on unknown plains

And lifts his head in fear (SP ll. 1-5)

The second stanza then sugars the pill:

Yet is he strong to suffer, and his mind 
Encounters all his evils unsubdued;

For happier days since at the breast he pined

He never knew. (11. 10-13)

In addition, the savage's strength in suffering is increased by the fact that all he sees around him are "men who all of his hard lot partake, / Repose in the same fear, to the same toil awake" (ll. 17-18). Those who suffer in the present, by contrast, are deprived even of this grim consolation, for they have known happier days and are confronted with other human beings who have been spared their own "sad reverse of fate" (1. 22). The fourth stanza then drives home the point:

Hence where Refinement's genial influence calls

The soft affections from their wintry sleep

And the sweet tear of Love and Friendship falls

The willing heart in tender joy to steep,

When men in various vessels roam the deep

Of social life, and turns of chance prevail

Various and sad, how many thousands weep

Beset with foes more fierce than e'er assail

The savage without home in winter's keenest gale. (11. 28-36)

It is hard not to see the point of Wordsworth's comparison, but Benis convincingly succeeds in doing so. For him, the opening stanzas show "how truly radical Wordsworth's position is" (2000: 67): by indicating how the savage "gathers strength from his isolating condition and the general lack of developed society" (67), Benis argues, Wordsworth actually "implies that any systematic reform [of society] predicated on existing extended, organized communities is doomed" (67). Where Wordsworth sees the savage as stronger - not happier - for not having received the mixed blessing - but nonetheless a blessing - of "Renifement's genial influence," Benis sees the savage as positively blessed in his state of unmixed isolation: "The opening stanzas, repeatedly emphasizing that the fortunate savage was 'without home,' conclude that any dealings with 'the deep / Of social life' inevitably lead to misery and oppression" (67-68).

On the strength of this strange insight, central to his intent to turn early Wordsworth into an advocate of homelessness, Benis rereads the Salisbury Plain poems as teaching us that "[o]nly in individual moments of human contact, which are now best epitomized by associations 
among vagrants, can even a splintered sense of personal freedom and fulfillment reside" (68). For Benis, therefore, the "most damaging overtly confronted ideologies in 'Salisbury Plain' concern the family and the home" (68). In striking contrast to Rieder, Benis sees Wordsworth discovering not a gap between the good world of the family and the bad world of the state, but rather a highly effective strategic alliance between the two spheres, which is zealously cultivated by counterrevolutionary ideologues such as Burke, who "went on to make the patriarchal family the linchpin in his crusade against revolution: " $[\mathrm{t}] \mathrm{o}$ be attached to the subdivision, to love the little platoon we belong to in society, is the first principle (the germ as it were) of public affections. It is the first link in the series by which we proceed towards a love to our country and to mankind" "(69-70).

Armed with this understanding of Wordsworth's vision, Benis unsurprisingly interprets the beaten-child episode as an illustration of Godwin's attacks on domestic life in the first edition of Political Justice: "the family, like the state that is modeled on it, creates discord and misery" (87). Whereas Rieder reads the Sailor's speech that concludes the episode as a defense of the family as the "more intimate setting where the characters' virtue is competent" (1997: 106), Benis sees it as yet another plea for the "sympathetic contact" and "unimpeded interchange" which are the blessings of homeless life alone (2000: 86):

The sailor invokes a generalized "bond of nature" as the element that should keep peace in the family of humanity. He also recognizes that, in both his own life and the scene before him, the sense of this ancient bond had been riven by the new laws of nation and family. The encounter itself bears out that the only bond that has any positive power is a provisional sense of engagement. (88)

The fact that the text explicitly qualifies this putative praise of homelessness as a disclosure of "homely truths" (ASP 1. 565), and further characterizes the Female Vagrant as a woman susceptible to the "homefelt force of sympathy sincere" (ASP 1.704), goes unnoticed in Benis's account.

The interest presented by Benis's misreading in this context is that it articulates what is missing in Rieder's reading, to wit "the broader perspective available to the poet" (Rieder 1997: 107) which could make sense of the acknowledged contradiction in Rieder's interpretation 
regarding the relation between family and state. Notwithstanding the questionable exegesis underpinning Benis's argument, it does help to put in clearer relief the central problem in Wordsworth's turn from "social and political phenomena" to the allegedly "more complex phenomena of human motives and behaviour" (SPP 12). What both Rieder and Benis recognize is Wordsworth's faltering attempt to formulate Hartman's law - "afford sympathy" - in the socio-political context where it is meant to matter. Rieder locates this sympathy in the home but, by his own admission, fails to demonstrate how it is supposed to travel to the public field of state-politics, if at all; Benis recognizes the potentially sinister ideological service to which domestic sympathy can be put and consequently locates Wordsworth's sympathy as he understands it outside both home and state, but thereby effectively confirms the real irresolution which the poem's melodramatic resolution cannot control. What neither critic queries, though, is the provenance of the infant figure triggering this ethical inquiry into the virtues of sympathy.

Rather than dressing it in the New Historicist detail of turn-of-thecentury child-beating, there is something to be said for tracing this infant in Wordsworth's text. As it happens, the word "infant" appears in two passages in each poem. One of these passages, shared by both texts, occurs in the woman's narrative of the happy early years of her marriage: "Three lovely infants lay within my breast / And often viewing their sweet smiles I sighed / And knew not why" (SP 11. 29193; ASP 11. 345-47). The other occurrence of the word in the first poem gives an articulate sense to that sigh. Just before the woman begins her tale, the narrator fixes his gaze on her breasts:

Like swans, twin swans, that when on the sweet brink

Of Derwent's stream the south winds hardly blow,

'Mid Derwent's water-lillies swell and sink

In union, rose her sister breasts of snow,

(Fair emblem of two lover's hearts that know

No separate impulse) or like infants played,

Like infants strangers yet to pain and woe. (SP 11. 208-14)

Discarding the swans and the lovers as appropriate tropes, the poem seizes upon the infants as figures releasing a damaging insight into the trauma of human existence: 
And are ye spread ye glittering dews of youth For this, - that Frost may gall the tender flower In Joy's fair breast with more untimely tooth? Unhappy man! thy sole delightful hour Flies first; it is thy miserable dower Only to taste of joy that thou may'st pine A loss, which rolling suns shall ne'er restore. New suns roll on and scatter as they shine No second spring, but pain, till death release thee, thine. ( $S P$ ll. 217-25)

The argument clearly recalls, inverts, and radicalizes the sketch of the hungry savage in the opening stanzas. ${ }^{7}$ What the modulation of that sketch in the present passage primarily reveals is its absence of purpose - an absence symptomatically denied in redemptive misreadings of the savage situation such as Benis's. The four opening stanzas merely posit a contrast between the past and the present as a difference between the homogeneity of unmitigated suffering and the heterogeneity of modern differentiation, the latter being explicitly linked to the function of memory as the faculty in charge of constituting difference. Yet the poem fails to develop this posited point coherently into a purposeful rhetoric of community for the present. The trope of the breast-infants, then, triggers the climactic culmination of this failure in the hyperbolical assumption of radical trauma. The strength of the savage is that, having always "pined," even "at the breast," and having never encountered anything "[b]ut men who all of his hard lot partake, / Repose in the same fear, to the same toil awake," he is immune to the workings of memory as a faculty producing difference. The curse of the present writ large on the faces of the infants "strangers yet to pain and woe" is that they are destined for a difference Wordsworth can only envisage as the life-long misery of "Unhappy man" as such. What this vision effectively reveals is the etymological literalization of sympathy itself as, precisely, shared suffering. For what is the state of the savage

7 Liu qualifies Wordsworth's comparison between savage and modern pain in these opening stanzas as "wholly insensitive to historical difference" (1989: 183). Tracing the short-circuit between this comparison and the narrator's crisis in the face of "Unhappy man" in stanza 25 of Salisbury Plain (curiously glossed over in Liu's comments on the tropology of pain generated by the Female Vagrant's breasts, 187-88) may help to furnish a further history for this indifference. 
imagined by Wordsworth if not a state of pure sympathy, in which each and everyone suffers the same? And what is our state as fallen infants if not this same condition of sad sympathy?

Read in this light, the infant trope bridges the gap between the past and the present, from which the poem sets out, by rewriting difference as more of the same, thereby disabling the notion of sympathy as a core element in an affirmative rhetoric of community ready to register difference. In the context of Wordsworth's attempt to develop an ideology predicated on sympathy, which Hartman, Gill, Rieder, Benis, and others have accurately recognized as his chief intent, the infant passage in the first Salisbury Plain poem is a disastrous moment of excessive imaginative reduction from which the second poem is still trying to recover.

The way in which Adventures on Salisbury Plain sets out to control the damage done is remarkably systematic, showing Wordsworth painstakingly trying to rescue the maximum: the woman's breasts that gave rise to the passage are revised out; but the figural swans they initially invited through simile are now literalized into real swans swimming on Derwent, thereby completing an unfinished stanza of the original poem ( $A S P$ 1l. 287; cp. $S P$ 1. 243); meanwhile, the figural "infants" develop into a real child - catachrestically called "infant" $(A S P 1.616,1.623)$ and significantly endowed with no language but a shrill scream - suffering real violence rather than the universal trauma of humankind. Most importantly, perhaps, the homiletic opening line of the first poem - "Hard is the life when naked and unhouzed" (SP 1. 1) - is modulated into the opening line of the Sailor's response to this infant suffering in his disclosure of "homely truths": "Tis a bad world, and hard is the world's law" (ASP 1. 658). With this last recovery, Wordsworth at once rehearses and erases the connection between savage sympathy and infant trauma that short-circuited the first poem, almost literally domesticating the infant figure by inserting it into the admittedly still "unhouzed" nuclear family as sympathy's last, politically incompetent, resort. It is perhaps one of Wordsworth's most revealing, because least confidently developed, attempts to establish the oxymoron of infant virtue which haunts his political imagination throughout. Read brutally, by rewriting the figure of the infant in the second poem, Wordsworth tries pressing it into the ideological service it failed to perform in the earlier text. His failure to perform this salvaging operation fully by finishing the poem to his own satisfaction signals at least a 
residual resistance to the trope of infant sympathy unsettled in Salisbury Plain. ${ }^{8}$

It is important that the second poem should have attempted this rhetorical child discipline in the first place. True, it must seem perverse to imagine Wordsworth simply abandoning the infant as a governing trope - he is, after all, the canonical blesser of babes at the breast, infants fathering their own future virtue by the force of sympathy. Even in the Immortality Ode, with its curious curse of the infant's fall into family and society, the child remains the focus of redemptive vision: "Heaven lies about us in our infancy" (1.66), and what remains of this "primal sympathy" (1. 184) is a lasting source of strength. ${ }^{9}$ Yet, as the compositional history of the Ode indicates, this lofty confidence comes at a price. As a sustained rereading of the Ode and its complicated genesis cannot be undertaken here, I will merely rehearse what I take to be the decisive turn in the text underway to its final version as "Intimations of Immortality from Recollections of Early Childhood." Unsurprisingly, that turn proves to be yet again the invention, or rather the recovery, of the infant as a trope that produces a release from difference.

\section{Recovered Infancy}

The clear break in diction between stanzas four and five of the Ode is generally received as a controlled shift in the overall argument of the poem; yet, as is well known but rarely reflected upon, Wordsworth probably wrote the first four stanzas some three months prior to the rest of the poem. ${ }^{10}$ Looked at in their own right, these lines make strange reading, as witness in this admittedly plodding prose paraphrase: "there

${ }^{8}$ This resistance, I would argue, must qualify Hartman's reading of the child-beating scene as Wordsworth's recognition of "the survival of his childhood strength of imagination" (Hartman 1964: 253).

${ }^{9}$ All quotations from the Ode are from the reading text of the 1807 version in Wordsworth 1983.

${ }^{10}$ As Jared Curtis notes in the Cornell edition of the poem, "Probably some or all of stanzas 1-4 composed March 27, 1802. Further composition - possibly including some or, less probably, all of stanzas 5-8 - on June 17, 1802. Most of the last seven stanzas probably composed, and the poem completed, early 1804, by March 6" (Wordsworth 1983: 271). 
was a time when I saw things I now can see no more; things are beautiful now, but something's missing, grieving me alone; then I heard something giving me relief, and now I'm happy again and feel at one with all. But there's a tree and a field and a flower telling me that something's missing and asking where it went." It does not take too much effort to read this account as a sober and self-concerned firstperson-singular version of the sympathy crisis in the earlier visions of the savage and the infant. Importantly, however, such an effort is not made by the text itself: in fact, the text as it stands in March 1802 does not endeavor to furnish any scheme in which its mild mood swings may make sense. It charts a movement from isolation as a result of unspecified loss, over joyous sympathy generated by an unidentified "timely utterance" (1.23) to renewed isolation articulated by singular objects, but it strikingly stops short of deriving any lesson from this movement.

The later continuation of the Ode famously is such a lesson: it recovers sympathy as a community-generating principle, bringing "soothing thoughts that spring / Out of human suffering" (ll. 186-87), and the crucial vehicle for this recovery operation is the instant infant, miraculously emerging in the first person plural in the resolutely homiletic opening line of stanza 5: "Our birth is but a sleep and a forgetting" (1. 58). The decisive difference between this infant and the beaten child in the second Salisbury Plain poem, however, is that its home is not in the family but quite emphatically outside human society in the "imperial palace" (1. 84) of God. The price to be paid for a solid foundation of sympathy is, it would appear, a resignation to religion, displacing the source of sympathy to the transcendental realm which is its all too familiar home. Yet for Wordsworth's text, which Stanley Cavell has felicitously characterized, be it with a different intent, as a "text of recovery" (1988: 50), this reactionary resignation yields material gains, for it allows him finally to reintegrate the trauma-tropes of Salisbury Plain that he was unable to salvage in the course of its revision ${ }^{11}$ :

${ }^{11}$ Even the Ode's opening formula may be determined more precisely than as a mere marker of the retrospective reflex constituting literary composition: apart from echoing Coleridge's 1800 poem "The Mad Monk" (Il. 9-10), Wordsworth's "There was a time when meadow, grove, and stream" also just about recalls the female wanderer's recollection of her young lover in Salisbury Plain: "There was a youth whose tender voice and eye / Might add fresh happiness to happiest days. /... his voice of love / Charmed the rude winds to sleep by river, field, or grove" ( $S P$ 11. 271-72; 278-79). 
And are ye spread, ye glittering dews of youth For this - that Frost may gall the tender flower In Joy's fair breast with more untimely tooth?

Unhappy man! thy sole delightful hour

Flies first. (SP 11. 217-20)

This insufferable insight in the untimely tooth of time itself is now released into the Ode's interpretation - or productive misreading - of the "timely utterance" (l. 23) that its opening stanzas failed to frame:

What though the radiance which was once so bright

Be now for ever taken from my sight,

Though nothing can bring back the hour

Of splendour in the grass, of glory in the flower;

We will grieve not, rather find

Strength in what remains behind,

In the primal sympathy

Which having been must ever be,

In the soothing thoughts that spring

Out of human suffering,

In the faith that looks through death,

In years that bring the philosophic mind. (11. 178-89)

Here at last, the critical contrast between the savage mind's unsubdued strength in pure sympathy and the despair of the imaginative equation of temporal difference to unrelieved suffering which paralyzed Wordsworth's imagination appears to be mastered. By relocating the infant in heaven, Wordsworth manages to posit human suffering as a force conducive to soothing thoughts. Yet this sympathetic strength in the face of suffering can only be purchased, it seems, at the cost of denying death itself. The textual trace of this transaction is the grave to which the infant is consigned, the "place of thought where we in waiting lie" (1. 123) and where Wordsworth's sympathy quite literally rests encrypted.

This encryption of human sympathy into death-denial invites a more focussed return to the contrast between savage indifference and post-savage differentiation at the outset of Salisbury Plain. Memory and comparison - the faculties crucially unavailable to Wordsworth's fictional and, by dint of this lack, strictly pre-human savage - institute the time and the space of difference through material inscriptions 
which produce "social life" as constitutively "various" (SP ll. 32-34). These inscriptions - language - take place and acquire time in matter that is dead to the processes of life: dead not for having once been alive but by virtue of the fact that, as the medium of inscription, this matter belongs to an order altogether different from life, including the death of life. As Paul de Man, transcribing Wordsworth's Essays upon Epitaphs, keeps reminding us, "[d]eath is a displaced name for a linguistic predicament" (1984: 81), and Wordsworth's savage fiction allows us to read this linguistic predicament as the retrospectively recognized traumatic collapse of the pre-historic life of nature into the history of material inscription we call culture: a practice of transmission radically alien to the genetic transmissions of life and able to survive only in the passage through dead matter. What is recorded in this passage is difference, the displaced name of which, as witnessed in the breakdown of Wordsworth's narrator in the face of the infants in Salisbury Plain, is indeed death: displaced, because rather than naming difference, the trope of death releases it into the order of natural life that difference has always already interrupted: "No second spring, but pain, till death release thee, thine" ( $S P$ 1. 225).

Effectively failing as a response to difference, this release into death merely rehearses the erasure of difference in the literal rendering of sympathy as the shared suffering of savage indifference, thereby missing precisely the "various" nature of "social life" which sympathy is supposed to address. The Ode's triumphant death-denial, prepared as it is by an entirely consistent dismissal of human society as artificial shape shifting and "endless imitation" (1. 107), treats this failure as a success and calls it "primal sympathy" (l. 184); denying death, it simultaneously dismisses language as the material predicament of difference by encrypting it, sub specie aeternitatis, as a mere epiphenomenon of the lived immortality of the soul born in and borne by God "who is our home" (1. 65). The awaited relief of real and general human suffering, which Wordsworth's earlier infant sympathy failed to imagine even in the bosom of the nuclear family, is transferred to an eternally thoughtful wait for the bosom of God - a wait in which the harrowing inarticulacy in the face of overwhelming iniquity is redeemed as the wisdom of infants who know their father near, to echo once more one of Wordsworth's chief successors in the tropological exploitation of infant virtue: 
And like a man in wrath the heart

Stood up and answered, 'I have felt.'

No, like a child in doubt and fear:

But that blind clamour made me wise;

Then was I as a child that cries,

But, crying, knows his father near;

And what I am beheld again

What is, and no man understands;

And out of darkness came the hands

That reach through nature, moulding men. (In Memoriam CXXIV, 11. 15-24)

If such is the price to be paid for sympathy as the regulative principle of an ethical rhetoric of community which can save us from the ravages of the last century, perhaps we should resist affording it. Such resistance is not a gratuitous resistance to religion: rather, it refuses the translation of both ethical and socio-political issues - the difference between them being delusive but not non-existent - into professions of faith on the back of a powerful trope. More succinctly, it refuses the abandonment of suffering for the sake of a figure. The fact that this ethico-political resistance to a rhetoric of sympathy is generated by the text itself indicates that there may be more than one way to be caught in the ethical turn: not merely by understanding the literary text as a vehicle for the sympathetic irnagination but rather by noting its failure to cover difference with the cloak of sympathy, a failure that renders it unreadable on its own temporal terms, though supremely intelligible in the recovered eyesight of God. To register this failure is to allow for a different articulation of the "material effectiveness" of literature - its power as a discursive practice that releases material traces of the crisis of imagination which can be justifiably called an ethical predicament inasmuch as it registers the resistance of the other - all others - to smooth and soothing sympathetic incorporation. The cry for resolution attending this crisis demands to be read rather than to be recovered in the shape of the answer whose ineffectiveness generated the crisis in the first place.

"No second spring, but pain, till death release thee, thine" (SP 1. 225). The additions to the manuscript of Salisbury Plain show Wordsworth's attempt to recover this "second spring" trope, too, but it 
is not until he revisits the matter in Guilt and Sorrow nearly half a century later that he appears to succeed in reintegrating it. The narrative generated by this textual sequence is further evidence of the resistance to reading difference which attends this recovery. In Salisbury Plain, the absence of a "second spring" names the crisis of sympathy in the face of human difference a crisis evaded in the decisive erasure of difference, through death, in nature, where spring springs eternal. In a first revision, probably undertaken already in 1794, Wordsworth attempts to restore the phrase by inserting it into an expanded account of the traveller's words of consolation in response to the female wanderer's narrative: it now figures, as "Joy's second spring," alongside phrases like "the general care man pays to man" and, especially significantly, "social orders all-protecting plan," as a fixed formula from the discourse of wishful thinking seeking to cover up distress by imagining a benevolent power governing society in much the same way as the a-historical cycles of regeneration govern nature. ${ }^{12}$ Qualifying these tropes as so many mystifications by no means amounts to a demystification of Wordsworth: the manuscript itself explicitly designates them as "[d]elusion fond" and as "[s]ounds that but served her deep breast to beguile" (SPP 111). The wanderer's breasts, which prompted the crisis of sympathy in the narrator of Salisbury Plain, return here as a "deep breast" receptive to a form of trauma management on the part of the traveller from which the narrator continues to measure his distance.

A second stage of revision soon after, in which the dramatic development of Salisbury Plain into Adventures on Salisbury Plain begins to take shape, shows Wordsworth recovering the "second spring" trope in a new passage depicting the traveller wandering the world in fear. At this stage, already burdened with the guilty conscience of a murderer, the traveller is said to be still receptive to nature's "tendency to pleasure known before" in the sense that "common cares" can "to his [heart or breast] a second spring restore," allowing his "heartstrings [to tremble] with responsive grief" in the face of "wretchedness" (SPP 115 ). If in the first revision the "second spring" figures as a mere phrase by means of which the traveller tries to engage sympathetically with the suffering woman, in the second revision it names that

\footnotetext{
12 The revisions just quoted are transcribed in $S P P 111$. For an alternative account, see Rieder 1997: 98-101.
} 
engagement itself as evidence of the beneficial power of nature. The narrator's critical reservation about sympathy as not just a necessary but, more importantly, a sufficient response to suffering gradually diminishes, and when the phrase finally reappears in Guilt and Sorrow, restored to its position in the consolation passage, the ideology of sympathy seems to be firmly in place:

True sympathy the Sailors's looks expressed,

His looks - for pondering he was mute the while.

Of social Order's care for wretchedness,

Of Time's sure help to calm and reconcile,

Joy's second spring and Hope's long-treasured smile,

'Twas not for him to speak - a man so tried.

Yet to relieve her heart, in friendly style

Proverbial words of comfort he applied,

And not in vain, while they went pacing side by side. (GS 11. 45159)

Gill notes that in this final version, the notion of "social Order's care" is no longer qualified as a "delusion fond"; instead, he adds, "the suggestion is that there is a benevolent order and that hope is possible, but that the sailor has put himself beyond them" (SPP 257). Such would indeed be the suggestion embraced by the ideology of sympathy. Yet it is equally possible to read the passage as an ironic repetition of the demystification of "social orders all-protecting plan" of the first revision, as a wishful trope intent on naturalizing the social. The Sailor's own trials at the very least invite this alternative construction, in which the "proverbial words of comfort" come to figure as the final recourse of impotent sympathy in the face of an injustice it is unable to address: the timeless utterances of pure ideology, whose marked repetition here as the disiecta membra of ideology can hardly fail to dislodge the fond delusion that the "social Order" was a living body in the first place, even as the performance of these prosthetic proverbs is emphatically credited with success. ${ }^{13}$ The fact that Guilt and Sorrow immediately moves on to the child-beating scene and its "appropriate lesson" (GS l. 512) that only the "bond of nature" (1. 508) can remedy

${ }^{13}$ Another, more famous performance of the proverbial in times of crisis, including the natural trope of the "second birth," that would be well worth rereading here occurs in Book X of the 1805 Prelude (11. 67-74). 
the inexorable "increase" in "pains" (1. 511) wrought by the "Bad ... world" (1. 505), indicates that, on Salisbury Plain, the miraculous recovery of the infant ideology of sympathy in the Immortality Ode continues to be undone, as a fond delusion, by the material inscriptions riddling Wordsworth's writing. ${ }^{14}$

\section{Intolerable Thought}

More concretely, the errant motif of the infant in Wordsworth's text suggests that Wordsworthian sympathy itself, derived as it is from the intimate imaginary identifications whose phantasmatic model is that of childhood, may be unhelpful in the development of visions addressing the incommensurable differences riddling what we must still call the human community. To trace this suspicion in the textual-recovery operations that constitute Wordsworth's tropology is to invite the thought of what Lisabeth During has recently called for as an ethics "on the far side of sympathy" (1998: 81). This suspicion is evidently not lost on the best apologist of Wordsworth's sympathetic imagination; exploring what he calls the sympathy paradox - "the more successful an expanding sensibility becomes, the more evidence we find of actual insensibility" (1997: 144) - Hartman forcefully registers what he calls "the crucial question":

The crucial question is now as always: how does one maintain compassion; what familial or formal pedagogy can achieve a widening of sensibility when that widening soon exhausts itself? The pro-life-debate in America as well as the animal rights movement are symptoms of a deep unease: they exhibit an imagination drawn to whatever is mute or helpless and they view that extension of feeling as the test of our humanity. But feelings are finite and so, as the sympathy paradox teaches, become overinvested, dogmatic, and even schizoid. As one segment of a forgotten or neglected reality is recovered, another fails, is not responded to, or is constructed as irredeemably alien. This self-

${ }^{14}$ For a further reflection on the "delusion bold" (1805 Prelude, VII, 1. 308) central to the ideology of sympathy, see my "Suffering, Sympathy, Circulation: Smith, Wordsworth, Coetzee (But There's a Dog)," forthcoming in European Journal of English Studies 7/3 (2003). 
protective indifference, however, does not always anesthesize conscience: often what is rejected hurts like a phantom limb. The perceived absence of compassion can then turn into a deliberate and dangerous coldness and seek to justify itself ideologically.... What we see mainly around us is pathology: a stressed sympathetic imagination and doctrines or defenses resulting from that. This pathology emerges most blatantly when cultures or nations different from us are demonized or one's own country is viewed not as a beloved community, an extension of family and a way of accommodating the finiteness of our energies and feelings, but as a sacrificial abstraction. (156-57)

Yet, even as he here intimates his recognition of the disturbing family resemblance between fascist demonization and familial ideology, Hartman refuses to abandon sympathy and returns to Wordsworth's infant virtue as a source of salvation ultimately unaffected by what he clearly recognizes as the "specter of a failure" (154) haunting its genesis. In Guilt and Sorrow, that specter appears as "[t]rue sympathy" (GS 1. 451): a sympathy which is essentially mute and which loses itself in a wishful resignation to injustice the moment it is performed as proverbial comfort proffered by one sensitive soul to another in an intimate exchange of timeless sentiment divorced from the structures of political representation.

What remains unthought in Hartman's return to Wordsworth's infant ideology - a faithful echo of Wordsworth's inability to abandon his disturbingly marked ideologization of sympathy as surrogate justice is the possibility of a credible alternative supplementing both the extended family and the pathological sacrificial abstraction of extreme nationalism, powered as they both are by personally imagined sympathy. In his perceptive review essay on The Fateful Question, Geoffrey Galt Harpham has puzzled over Hartman's "almost purposeful" avoidance of the concept of "society" (Harpham 1999: 218), which, as it is defined by Raymond Williams, "actually corresponds closely to Hartman's sense of Wordsworth in that it denotes a diverse polity, an ethical and civic structure held together by voluntary association based on shared interests and values" (219). Yet this avoidance, I would argue, if such it be, is less decisive than the avoidance in this specific connection of an alternative structure in which personal volition and substantially subjective sharing are themselves displaced (strictly 
speaking alienated) and which is consequently doomed, at least and by definition from the perspective of sympathetic society, to appear only as a vaguely threatening "apparatus of power" (Harpham 1999: 13), rather than as a genuinely radical, because profoundly unnatural, implementation of the political representation of sympathy beyond lived sentiment. What remains unthought here, to hazard an affirmation at last, is not so much "society" but a notion of the state (or State) materially representing an order of care that we cannot afford to feel or even think for ourselves, by instituting a resolutely timely structure of difference that offers real relief rather than charity, impersonal responsibility rather than the gratifying glow of a good conscience waiting to recover from the sympathy paradox. Performing sympathy as a "productive paradox" (Rieder 1997: 224), rather than aestheticizing it all the way to immortality, this necessarily expensive structure (only two things in life are certain) would require the recovery of, say, for now, the welfare state as an alternative response to the pathology of the present; but it would have to be a welfare state complicated beyond recognition, predicated on an ethics that challenges private conscience by exceeding its imaginative grasp, not the now outdated compromise consigned to the suspended animation of English national heritage that goes by that name. Perhaps Hartman is right: Wordsworth did shape a specifically English - and increasingly global - culture unable to entertain, let alone join, a genuinely political structure which it is hard to sympathize with precisely because it does not suffer intimate imaginative identifications, least of all as a family prepackaged for immediate tele-mediation. And for once, the then leader of the British Conservative Party may have been right too when he declared in 2000 that high taxes drive out good conscience. ${ }^{15}$ But instead of leading to "a deep cynicism about the institutions that give our lives moral shape,"

${ }^{15}$ Statement by William Hague in an address broadcast by the BBC on April 13, 2000. The gist of it was repeated in a pre-election speech delivered in December 2000: "Conservatives believe high taxes damage prosperity, drive away tomorrow's entrepreneurs, undermine a good conscience, generosity, and a sense of personal responsibility and lead to a deep cynicism about the institutions that give our lives moral shape. Low taxes are not just the basis of a dynamic economy, but also the foundation of a compassionate, responsible and free society." Quoted from http://news.bbc.co.uk/2/hi/uk news/politics/1055499.stm (October 21, 2003). The fact that the underlying conception of the state in this compassionate conservatism barely differs from the conception of the state in Britain's New Labour may offer further evidence for Hartman's claim. 
the impersonal bad conscience that constitutes the super-state at least entertains the promise of a shift in the shape of our lives that would translate sympathy beyond the confines of domesticated justice. Wordsworth's memory deserves this "intolerable thought" (GS 1. 659).

\section{Works Cited}

Benis, Toby R. 2000. Romanticism on the Road: The Marginal Gains of Wordsworth's Homeless. Houndmills: Macmillan.

Buell, Lawrence. 1999. "Introduction: In Pursuit of Ethics." PMLA 114/1: 7-19.

Caruth, Cathy. 1996. "An Interview with Geoffrey Hartman." Studies in Romanticism 35/4: 631-52.

Cavell, Stanley. 1988. In Quest of the Ordinary: Lines of Skepticism and Romanticism. Chicago: University of Chicago Press.

Coleridge, Samuel Taylor. 1969 [1912]. Poetical Works. Ed. Ernest Hartley Coleridge. London: Oxford University Press.

Connors, Steven. 1996. "Honour Bound." Times Literary Supplement, 5 January: 24-26.

De Graef, Ortwin. 2003. "Suffering, Sympathy, Circulation: Smith, Wordsworth, Coetzee (But There's a Dog)." European Journal of English Studies 7/3, forthcoming.

De Man, Paul. 1984 [1956]. The Rhetoric of Romanticism. New York: Columbia University Press.

During, Lisabeth. 1998. "The Concept of Dread: Sympathy and Ethics in Daniel Deronda." In Jane Adamson, Richard Freadman, and David Parker, eds. Renegotiating Ethics in Literature, Philosophy, and Theory. Cambridge: Cambridge University Press, pp. 65-83.

Gill, Stephen. 1998. Wordsworth and the Victorians. Oxford: Clarendon Press.

Hadfield, Andrew, Dominic Rainsford, and Tim Woods. 1999. "Introduction: Literature and the Return to Ethics." In Andrew Hadfield, Dominic Rainsford, and Tim Woods, eds. The Ethics in Literature. London: Macmillan, pp. 1-14.

Hague, William. 2000. Address broadcast by the BBC on April 13. http://news.bbc.co.uk/2/hi/uk news/politics/1055499.stm (October 21, 2003).

Harpham, Geoffrey Galt. 1992. Getting It Right: Language, Literature, 
and Ethics. Chicago: University of Chicago Press.

—. 1999. Shadows of Ethics: Criticism and the Just Society. Durham: Duke University Press.

Hartman, Geoffrey H. 1964. Wordsworth's Poetry, 1987-1814. New Haven: Yale University Press.

—. 1997. The Fateful Question of Culture. New York: Columbia University Press.

—. 1999. A Critic's Journey: Literary Reflections, 1958-1998. New Haven: Yale University Press.

Liu, Alan. 1989. Wordsworth: The Sense of History. Stanford: Stanford University Press.

Nussbaum, Martha C. 1995. Poetic Justice: The Literary Imagination and Public Life. Boston: Beacon Press.

-. 1998. "Exactly and Responsibly: A Defense of Ethical Criticism." Philosophy and Literature 22/2: 343-65.

Rieder, John. 1997. Wordsworth's Counterrevolutionary Turn: Community, Virtue, and Vision in the 1790s. Newark: University of Delaware Press.

Roe, Nicholas. 1988. Wordsworth and Coleridge: The Radical Years. Oxford: Clarendon Press.

Simpson, David. 1987. Wordsworth's Historical Imagination: The Poetry of Displacement. London: Methuen.

Tennyson, Alfred. 1989. Tennyson: A Selected Edition. Ed. Christopher Ricks. Harlow: Longman.

Wordsworth, William. 1975. The Salisbury Plain Poems of William Wordsworth. Ed. Stephen Gill. The Cornell Wordsworth. Ithaca: Cornell University Press.

—. 1979. The Prelude: 1799, 1805, 1850. Ed. Jonathan Wordsworth, M. H. Abrams, and Stephen Gill. New York: Norton.

-. 1983. Poems, in Two Volumes, and Other Poems, 1800-1807. Ed. Jared R. Curtis. The Cornell Wordsworth. Ithaca: Cornell University Press. 